\title{
Knowledge and Perception of Healthcare Professionals about the Need for Radiopharmacists in Hospitals in the Philippines
}

\author{
Rhian Jaymar Ramil1,2, Ma Danica Ines-Ramil',2, Janelyn Viado-Rojas ${ }^{2, \star}$, Learni Magdalena Bautista ${ }^{1}$ \\ ${ }^{1}$ The Graduate School, Centro Escolar University, San Miguel, Manila, PHILIPPINES. \\ ${ }^{2}$ Department of Pharmacy, College of Health Sciences, Mariano Marcos State University, City of Batac, llocos Norte, PHILIPPINES.
}

\begin{abstract}
Background: In most Asian countries, nuclear pharmacy practice is not an emerging specialty area. Radiopharmacy is considered to be a dearth career in the Philippines. This study attempts to explore on the need for radiopharmacists in the Philippines by assessing initially the knowledge and perception of healthcare professionals working in hospitals. Materials and Methods: A cross-sectional survey using a self-administered questionnaire was employed to 165 respondents in llocos Norte and llocos Sur. Data were recorded and analyzed using the SPSS 20. Results: On the whole, results showed that most respondents were aware about radiopharmaceuticals. Moreover, healthcare professionals strongly agreed that radiopharmacists are needed in the country. And, patient safety was on the top priority as strongly agreed by the healthcare professionals. Conclusion: Respondents regarded that radiopharmacists are accepted and needed in the Philippines. The role of radiopharmacists complements with other healthcare professionals in optimizing proper use of radiopharmaceuticals towards quality patient health outcomes and patient safety.
\end{abstract}

Key words: Radiopharmacist, Nuclear pharmacy, Radiopharmaceuticals, Patient safety, Healthcare professionals, Hospitals.

\section{INTRODUCTION}

Nuclear pharmacy practice started in the United States of America in $1960 .{ }^{1}$ Nuclear pharmacy is defined as a unique branch of pharmacy services that focuses on the proper, safe management and use of radiopharmaceuticals. ${ }^{2} \mathrm{~A}$ nuclear pharmacist or radiopharmacist, as a member of the nuclear medicine team, specializes in the procurement, compounding, quality control testing, dispensing, distribution and monitoring of radiopharmaceuticals. ${ }^{3}$ In addition, Patidar ${ }^{3}$ and associates mentioned that the practice of nuclear pharmacy is the contributions by radiopharmacists, particularly in areas such as product selection, drug interactions and interferences and assisting the physician in providing relevant information as to the safety and effects of radiopharmaceuticals.

In developed countries, the practice of nuclear pharmacy is already established and well-recognized by the medical community. ${ }^{4}$ On the contrary, Parasuraman et al, ${ }^{5}$ reported that the awareness about the role and availability of pharmacists in nuclear medicine was inadequate in some developing Asian countries. Similarly, a study conducted in Brazil highlighted that all hospitals considered that radiopharmacists are not needed in their nuclear medicine units. ${ }^{3}$ In the Philippines, there is already an increasing trend in utilizing radiopharmaceuticals. Still, only a few hospitals have made attempts to provide nuclear pharmacy services to nuclear medicine or radiology departments. ${ }^{6}$
DOI: 10.5530/ijopp.15.1.6

Address for correspondence: Prof. Janelyn Viado-Rojas Associate Professor, Department of Pharmacy, College of Health Sciences Mariano Marcos State University, 2906 City of Batac, llocos Norte, PHILIPPINES

Email id: jvrojas@mmsu. edu.ph

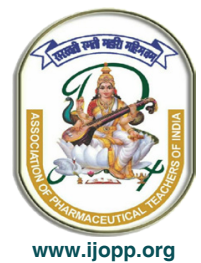


A pharmacist has a professional responsibility and obligation to become involved with drug use including contrast agents and radiopharmaceuticals utilized within hospitals with imaging facilities. Beach ${ }^{7}$ mentioned that the management of radiopharmaceuticals can be accomplished with a collaborative approach with the pharmacist for quality pharmaceutical care. Thus, this research initially explores the need for radiopharmacists in hospitals with imaging facilities and interventional radiology in the Philippines by evaluating the knowledge and perception of healthcare professionals.

\section{MATERIALS AND METHODS}

A cross-sectional survey was employed in this study. A self-administered questionnaire was distributed to the healthcare professionals in Ilocos Norte and Ilocos Sur, assessing their knowledge and perception on the need for radiopharmacist in hospitals in the Philippines, a countryside perspective. Prior to the conduct of the study, ethical approval was sought from the Institutional Ethics Review Committee of the Centro Escolar University.

Private and government hospitals (Level 2 and 3 hospitals) with imaging facilities and interventional radiology in Ilocos Norte and Ilocos Sur were selected as the study sites. Five (5) sites were included, namely; Mariano Marcos Memorial Hospital and Medical Center (MMMH and MC), Laoag City General Hospital (LCGH), Gov. Roque B. Ablan Sr. Memorial Hospital (GRBASMH), Metro Vigan Cooperative Hospital (MVCH) and Ilocos Sur Provincial Hospital - Gabriela Silang (ISPH). The sample size was computed based on $80 \%$ confidence level, 0.5 standard deviations and a margin of error (confidence interval) of $+/-5 \%$, which resulted in a 165-respondents. Convenience sampling was conducted to include healthcare professionals, such as physicians, pharmacists, nurses, medical technologists and radiological technologists, regardless of employment status. Allocation of respondents was distributed equally per profession.

A validated survey questionnaire was adapted from Riyasha et al,. ${ }^{8}$ with slight modifications. The questionnaire consisted of demographic data and 17 questions covering three main areas of interest. These areas include (1) awareness about radiopharmaceuticals among healthcare professionals, (2) opinion about the need for a radiopharmacist and (3) opinion of healthcare professionals about patient safety. The slightly modifiedquestionnaire was then subjected to pilot-testing to ten (10) healthcare professionals to ensure content validity.
Before the gathering of data, permission was sought from the Chief of Hospital. Informed consent was reviewed and signed by the respondents prior to the administration of the questionnaire. Data were analyzed using statistical software (SPSS) version 20. Descriptive statistics were applied. Weighted mean and analysis of variance were also used.

\section{RESULTS}

A total of 165 respondents were included in the study. Table 1 reveals that half of the respondents are adults aged 36 and below (57\%). The majority are females $(63.6 \%)$. Most of the respondents are working in Mariano Marcos Memorial Hospital and Medical Center (26.1\%), while Laoag City General Hospital (10.3\%) is the least. Almost half of the respondents have working experience in the hospital from 1 to 5 years (45.5\%). Missing data or no response were noted due to a few respondents' non-disclosure on their ages and years of working.

\section{Awareness about Radiopharmaceuticals among Healthcare Professionals}

Table 2 presents the outcomes of the radiopharmaceutical awareness of healthcare professionals. Interestingly, most

\begin{tabular}{ccc}
\multicolumn{3}{c}{ Table 1: Demographics of the respondents. } \\
\hline Variable & Frequency $\mathbf{n = 1 6 5}$ & Percentage \\
\hline$\geq 61$ & Age \\
$55-60$ & 4 & 2.4 \\
$37-54$ & 9 & 5.5 \\
$\leq 36$ & 41 & 24.8 \\
NR & 94 & 57 \\
& 17 & 10.3 \\
Male & Sex & \\
Female & 60 & 36.4 \\
& 105 & 63.6 \\
MMMH & Study Sites & \\
LCGH & 43 & 26.1 \\
GRBASMH & 17 & 10.3 \\
MVCH & 35 & 21.2 \\
ISPH & 36 & 21.8 \\
& 34 & 20.6 \\
less than 1 & Number of Years Working & \\
1 - 5 & 21 & 12.7 \\
$6-10$ & 75 & 45.5 \\
more than 10 & 27 & 16.4 \\
NR & 36 & 21.8 \\
\hline
\end{tabular}

$\mathrm{NR}=$ missing data or no response 
Table 2: Awareness about radiopharmaceuticals among healthcare professionals

\begin{tabular}{|c|c|c|c|c|c|c|c|c|c|}
\hline \multirow{2}{*}{\multicolumn{3}{|c|}{ Item }} & \multicolumn{7}{|c|}{ Healthcare Professionals (Mean Score \pm SEM) } \\
\hline & & & MDs & RNs & RPhs & RMTs & RRTs & Total & Sig. \\
\hline \multicolumn{3}{|c|}{$\begin{array}{l}\text { Radiopharmaceuticals are widely used for diagnosis and } \\
\text { therapy }\end{array}$} & $\begin{array}{c}4.03 \\
\pm 0.110\end{array}$ & $\begin{array}{c}4.03 \\
\pm 0.119\end{array}$ & $\begin{array}{c}4.27 \\
\pm 0.125\end{array}$ & $\begin{array}{c}3.82 \\
\pm 0.102\end{array}$ & $\begin{array}{c}4.18 \\
\pm 0.110\end{array}$ & $\begin{array}{c}4.07 \\
\pm 0.051\end{array}$ & 0.057 \\
\hline \multicolumn{3}{|c|}{$\begin{array}{l}\text { Radiopharmaceuticals are one of the reasons for } \\
\text { radiation contamination }\end{array}$} & $\begin{array}{c}3.93 \\
\pm 0.115\end{array}$ & $\begin{array}{c}3.79 \\
\pm 0.155\end{array}$ & $\begin{array}{c}3.91 \\
\pm 0.126\end{array}$ & $\begin{array}{c}3.61 \\
\pm 0.144\end{array}$ & $\begin{array}{c}4 \\
\pm 0.115\end{array}$ & $\begin{array}{c}3.85 \\
\pm 0.059\end{array}$ & 0.238 \\
\hline \multicolumn{3}{|c|}{$\begin{array}{c}\text { Contamination may occur due to improper handling } \\
\text { procedures }\end{array}$} & $\begin{array}{c}4.42 \\
\pm 0.098\end{array}$ & $\begin{array}{c}4.48 \\
\pm 0.088\end{array}$ & $\begin{array}{c}4.48 \\
\pm 0.124\end{array}$ & $\begin{array}{c}4.18 \\
\pm 0.141\end{array}$ & $\begin{array}{c}4.45 \\
\pm 0.098\end{array}$ & $\begin{array}{c}4.41 \\
\pm 0.050\end{array}$ & 0.267 \\
\hline \multicolumn{3}{|c|}{$\begin{array}{l}\text { By following proper safety techniques, radiation } \\
\text { contamination can be reduced up to some extent }\end{array}$} & $\begin{array}{c}4.39 \\
\pm 0.086\end{array}$ & $\begin{array}{c}4.33 \\
\pm 0.112\end{array}$ & $\begin{aligned} & 4.52 \\
\pm & 0.124\end{aligned}$ & $\begin{array}{c}4.24 \\
\pm 0.145\end{array}$ & $\begin{aligned} & 4.45 \\
\pm & 0.088\end{aligned}$ & $\begin{array}{c}4.39 \\
\pm 0.051\end{array}$ & 0.481 \\
\hline \multicolumn{3}{|c|}{$\begin{array}{l}\text { Proper disposal of radiopharmaceuticals is } \\
\text { necessary to reduce the contamination }\end{array}$} & $\begin{array}{c}4.54 \\
\pm 0.088 \\
\end{array}$ & $\begin{array}{c}4.48 \\
\pm 0.116\end{array}$ & $\begin{array}{c}4.67 \\
\pm 0.112 \\
\end{array}$ & $\begin{array}{c}4.42 \\
\pm 0.151 \\
\end{array}$ & $\begin{array}{c}4.58 \\
\pm 0.098 \\
\end{array}$ & $\begin{array}{c}4.54 \\
\pm 0.051 \\
\end{array}$ & 0.636 \\
\hline Legend & ${ }^{*} p<0.05$ & & & & & & & & \\
\hline Likert & Range & Verbal Interpretation & & & & & & & \\
\hline 5 & $4.20-5.00$ & Strongly Agree & & & & & & & \\
\hline 4 & $3 \cdot 40-4.19$ & Agree & & & & & & & \\
\hline 3 & $2.60-3.39$ & Neither Disagree nor Agree & & & & & & & \\
\hline 2 & $1.80-2.59$ & Disagree & & & & & & & \\
\hline 1 & 1:00-1.79 & Strongly Disagree & & & & & & & \\
\hline
\end{tabular}

respondents were strongly aware of radiopharmaceutical concepts. Generally, respondents agreed (4.07) that radiopharmaceuticals are widely used for diagnosis and therapy. That trend is most evident among pharmacists (4.27) and least among medical technologists (3.82). It is agreed (3.85) among professionals that radiopharmaceuticals are one of the reasons for radiation contamination. There was a marked manifestation of this trend among radiologic technologists (4) and least evident among medical technologists (3.61). It can also be noted that contamination may occur due to improper handling procedures, as strongly agreed (4.41) among respondents. This evidence was primarily shared among pharmacists and nurses (4.48) and least among medical technologists (4.18). It was strongly agreed (4.39) among healthcare professionals that radiation contamination can be reduced to some extent by following proper safety techniques. This mark was primarily disclosed among pharmacists (4.52), followed by radiological technologists, physicians, nurses, and medical technologists. Moreover, all healthcare professionals strongly agreed (4.54) that proper disposal of radiopharmaceuticals is necessary to reduce contamination as also evidently observed among pharmacists (4.67).

\section{Opinion about the Need for a Radiopharmacists}

On the whole, Table 3 represents the responses of healthcare professionals on the need for radio pharmacists in the Philippines. Remarkably, respondents strongly agreed on all items or statements addressed in this domain.

Specifically, respondents strongly agreed (4.52) that a knowledgeable person is needed to order and receive radiopharmaceuticals. This evidence was marked strong among pharmacists (4.70) and least among nurses (4.27). When it comes to compounding and preparation of radiopharmaceuticals, respondents also strongly agreed that a responsible person is necessary. This perception was evident most among pharmacists (4.82) and least among nurses and radiological technologists (4.39). The same trend was observed in handling radiopharmaceuticals, healthcare professionals strongly agreed (4.58) that properly trained personnel are essential. This trend was most manifested among pharmacists (4.76) and least among nurses and radiologic technologists (4.42). Moreover, healthcare professionals strongly agreed (4.41) that doctors need assistants in patient monitoring in radiopharmaceutical usage as evidently perceived most among pharmacists (4.64) and least among radiological technologists (4.21). When radiopharmacist was specified and included in the handling, patient monitoring and counseling on radiopharmaceuticals, respondents strongly agreed (4.38). This was evidently seen most among pharmacists (4.64), followed by nurses, physicians and medical technologists and radiological technologists. Also, respondents strongly agreed (4.35) that radiopharmacist is considered to be helpful for other healthcare professionals involved in radiopharmacy. Such perception was primarily shared by pharmacists (4.57). Overall, radiopharmacists are necessary for the Philippines, as strongly agreed (4.28) by all healthcare professionals. This evidence was particularly disclosed most by the pharmacists (4.48) and least among physicians and radiologic technologists (4.18).

Indian Journal of Pharmacy Practice, Vol 15, Issue 1, Jan-Mar, 2022 
Table 3: Opinion about the need for radiopharmacist.

\begin{tabular}{|c|c|c|c|c|c|c|c|}
\hline \multirow{2}{*}{ Item } & \multicolumn{7}{|c|}{ Healthcare Professionals (Mean Score \pm SEM) } \\
\hline & MDs & RNs & RPhs & RMTs & RRTs & Total & Sig. \\
\hline $\begin{array}{l}\text { For the ordering and receiving of } \\
\text { radiopharmaceuticals, a knowledgeable person is } \\
\text { needed. }\end{array}$ & $\begin{array}{c}4.55 \\
\pm 0.098\end{array}$ & $\begin{array}{c}4.27 \\
\pm 0.132\end{array}$ & $\begin{array}{c}4.70 \\
\pm 0.081\end{array}$ & $\begin{array}{r}4.52 \\
\pm 108\end{array}$ & $\begin{array}{c}4.55 \\
\pm 0.116\end{array}$ & $\begin{array}{c}4.52 \\
\pm 0.049\end{array}$ & 0.098 \\
\hline $\begin{array}{c}\text { For the compounding and/or preparation of } \\
\text { radiopharmaceuticals, it is necessary to have a } \\
\text { responsible person }\end{array}$ & $\begin{array}{c}4.67 \\
\pm 0.083\end{array}$ & $\begin{array}{c}4.39 \\
\pm 0.097\end{array}$ & $\begin{array}{c}4.82 \\
\pm 0.068\end{array}$ & $\begin{array}{c}4.55 \\
\pm 0.088\end{array}$ & $\begin{array}{c}4.39 \\
\pm 0.096\end{array}$ & $\begin{array}{c}4.56 \\
\pm 0.041\end{array}$ & $0.002^{*}$ \\
\hline $\begin{array}{c}\text { Properly trained personnel are essential for } \\
\text { handling radiopharmaceutical in hospital } \\
\text { radiopharmacy }\end{array}$ & $\begin{array}{c}4.67 \\
\pm 0.083\end{array}$ & $\begin{array}{c}4.42 \\
\pm 0115\end{array}$ & $\begin{array}{c}4.76 \\
\pm 0.076\end{array}$ & $\begin{array}{c}4.61 \\
\pm 0.086\end{array}$ & $\begin{array}{c}4.42 \\
\pm 0.097\end{array}$ & $\begin{array}{c}4.58 \\
\pm 0.042\end{array}$ & $0.04^{*}$ \\
\hline $\begin{array}{l}\text { Doctors need assistants in patient monitoring } \\
\text { in radiopharmaceutical usage as the number of } \\
\text { patients are increasing }\end{array}$ & $\begin{array}{c}4.42 \\
\pm 0.107\end{array}$ & $\begin{array}{c}4.42 \\
\pm 0.115\end{array}$ & $\begin{array}{c}4.64 \\
\pm 0.105\end{array}$ & $\begin{array}{c}4.36 \\
\pm 0.105\end{array}$ & $\begin{array}{c}4.21 \\
\pm 0.129\end{array}$ & $\begin{array}{c}4.41 \\
\pm 0.049\end{array}$ & 0.105 \\
\hline $\begin{array}{l}\text { It is necessary to have a radio pharmacist for } \\
\text { proper handling and patient monitoring and } \\
\text { counselling }\end{array}$ & $\begin{array}{c}4.33 \\
\pm 0.103\end{array}$ & $\begin{array}{c}4.36 \\
\pm 0.096\end{array}$ & $\begin{array}{c}4.64 \\
\pm 0.096\end{array}$ & $\begin{array}{c}4.33 \\
\pm 0.103\end{array}$ & $\begin{array}{c}4.27 \\
\pm 0.125\end{array}$ & $\begin{array}{c}4.38 \\
\pm 0.047\end{array}$ & 0.124 \\
\hline $\begin{array}{l}\text { Radio pharmacist is considered to be helpful } \\
\text { for other healthcare professionals involved in } \\
\text { radiopharmacy }\end{array}$ & $\begin{array}{c}4.42 \\
\pm 0.098\end{array}$ & $\begin{array}{c}4.27 \\
\pm 0.109\end{array}$ & $\begin{array}{c}4.57 \\
\pm 0.106\end{array}$ & $\begin{array}{c}4.30 \\
\pm 0.092\end{array}$ & $\begin{array}{c}4.15 \\
\pm 0.116\end{array}$ & $\begin{array}{c}4.35 \\
\pm 0.048\end{array}$ & 0.055 \\
\hline $\begin{array}{c}\text { In the Philippines, it is necessary to have a radio } \\
\text { pharmacist }\end{array}$ & $\begin{array}{c}4.18 \\
\pm 0.111\end{array}$ & $\begin{array}{c}4.27 \\
\pm 0.109\end{array}$ & $\begin{array}{c}4.48 \\
\pm 0.108\end{array}$ & $\begin{array}{c}4.30 \\
\pm 0.111\end{array}$ & $\begin{array}{c}4.18 \\
\pm 0.127\end{array}$ & $\begin{array}{c}4.28 \\
\pm 0.051\end{array}$ & 0.311 \\
\hline
\end{tabular}

$\begin{array}{lll}\text { Legend } & { }^{*} p<0.05 & \\ \text { Likert } & \text { Range } & \text { Verbal Interpretation } \\ 5 & 4.20-5.00 & \text { Strongly Agree } \\ 4 & 3.40-4.19 & \text { Agree } \\ 3 & 2.60-3.39 & \text { Neither Disagree nor Agree } \\ 2 & 1.80-2.59 & \text { Disagree } \\ 1 & 1: 00-1.79 & \text { Strongly Disagree }\end{array}$

\section{Opinion of Healthcare Professionals about Patient Safety}

In general, Table 4 reveals the views about patient safety where respondents strongly agreed that patient education is needed about the side effects, safety precautions and elimination of the radiopharmaceuticals.

Specifically, respondents posted strongly agree (4.47) when asked about the necessity to educate patients about radiopharmaceuticals. This evidence was seen most among healthcare professionals (4.48). At the same time, healthcare professionals strongly agreed (4.61) that it is necessary to make patients aware of safety precautions. This was manifested most among pharmacists (4.69) and least among medical technologists (4.54). Moreover, educating patients about side effects should be done as strongly agreed (4.63) among respondents. This trend was seen primarily by physicians (4.79) followed by pharmacists (4.72), nurses (4.67), medical and radiologic technologists (4.54). Furthermore, respondents strongly agreed (4.46) that it is necessary to make the patients aware of the elimination of the drug. This opinion was most evident among physicians (4.67) and least among medical technologists and radiologic technologists (4.33). Respondents strongly agreed (4.55) that patient monitoring is necessary for excretion to avoid contamination as perceived most by pharmacists (4.63) and least by the radiologic technicians (4.48).

\section{DISCUSSION}

This research was initially conducted to determine healthcare professionals' countryside perspective on the need for radiopharmacists or nuclear pharmacists in the Philippines. In the current setting, radiopharmaceuticals are not solely handled and managed by a pharmacist. Medical technologists and radiochemists mostly handle it. The Philippine Nuclear Research Institute describes an authorized nuclear pharmacist who has current board certification by the Professional Regulatory Commission as a pharmacist, medical technologist, chemist, or other related fields. ${ }^{9}$ Moreover, the Philippine Society of Nuclear Medicine emphasized the development of a specialized undergraduate program, a BS in Nuclear Medicine Technologist. ${ }^{6}$ This program offers courses on radiopharmacy and radiochemistry and eventually, these technologists will work closely with nuclear medicine physicians. Moreover, there are only a few radiopharmacists in the country. 
Table 4: Opinion of healthcare professionals about patient safety.

\begin{tabular}{|c|c|c|c|c|c|c|c|c|c|}
\hline \multirow{2}{*}{\multicolumn{3}{|c|}{ Item }} & \multicolumn{7}{|c|}{ Healthcare Professionals (Mean Score \pm SEM) } \\
\hline & & & MDs & RNs & RPhs & RMTs & RRTs & Total & Sig. \\
\hline \multicolumn{3}{|c|}{$\begin{array}{l}\text { It is necessary to educate the patients about } \\
\text { radiopharmaceuticals }\end{array}$} & $\begin{array}{c}4.48 \\
\pm 0.116\end{array}$ & $\begin{array}{c}4.48 \\
\pm 0.098\end{array}$ & $\begin{array}{c}4.48 \\
\pm 0.098\end{array}$ & $\begin{array}{c}4.48 \\
\pm 0.088\end{array}$ & $\begin{array}{c}4.42 \\
\pm 0.123\end{array}$ & $\begin{array}{c}4.47 \\
\pm 0.047\end{array}$ & 0.992 \\
\hline \multicolumn{3}{|c|}{$\begin{array}{l}\text { It is necessary to make patients aware about safety } \\
\text { precautions }\end{array}$} & $\begin{array}{c}4.67 \\
\pm 0.083\end{array}$ & $\begin{array}{c}4.57 \\
\pm 0.087\end{array}$ & $\begin{array}{c}4.69 \\
\pm 0.081\end{array}$ & $\begin{array}{c}4.54 \\
\pm 0.098\end{array}$ & $\begin{array}{c}4.57 \\
\pm 0.115\end{array}$ & $\begin{array}{c}4.61 \\
\pm 0.042\end{array}$ & 0.774 \\
\hline \multicolumn{3}{|c|}{ Patients should be educated about side effects } & $\begin{array}{c}4.79 \\
\pm 0.072\end{array}$ & $\begin{array}{c}4.67 \\
\pm 0.083\end{array}$ & $\begin{array}{c}4.72 \\
\pm 0.079\end{array}$ & $\begin{array}{c}4.54 \\
\pm 0.098\end{array}$ & $\begin{array}{c}4.54 \\
\pm 0.124\end{array}$ & $\begin{array}{c}4.63 \\
\pm 0.042\end{array}$ & 0.081 \\
\hline \multicolumn{3}{|c|}{$\begin{array}{l}\text { It is necessary to make aware the patients about } \\
\text { elimination of the drug }\end{array}$} & $\begin{array}{c}4.67 \\
\pm 0.083\end{array}$ & $\begin{array}{c}4.39 \\
\pm 0.123\end{array}$ & $\begin{array}{c}4.58 \\
\pm 0.107\end{array}$ & $\begin{array}{c}4.33 \\
\pm 0.103\end{array}$ & $\begin{array}{c}4.33 \\
\pm 0.103\end{array}$ & $\begin{array}{c}4.46 \\
\pm 0.047\end{array}$ & 0.073 \\
\hline \multicolumn{3}{|c|}{$\begin{array}{l}\text { Patient monitoring is necessary for excretion to avoid } \\
\text { contamination }\end{array}$} & $\begin{array}{c}4.52 \\
\pm 0.088\end{array}$ & $\begin{array}{r}4.61 \\
\pm 0.086\end{array}$ & $\begin{array}{c}4.63 \\
\pm 0.085\end{array}$ & $\begin{aligned} & 4.52 \\
\pm & 0.088\end{aligned}$ & $\begin{array}{c}4.48 \\
\pm 0.116\end{array}$ & $\begin{array}{c}4.55 \\
\pm 0.042\end{array}$ & 0.741 \\
\hline Legend & $*_{p}<0.05$ & & & & & & & & \\
\hline Likert & Range & Verbal Interpretation & & & & & & & \\
\hline 5 & $4.20-5.00$ & Strongly Agree & & & & & & & \\
\hline 4 & $3 \cdot 40-4 \cdot 19$ & Agree & & & & & & & \\
\hline 3 & $2.60-3.39$ & Neither Disagree nor Agree & & & & & & & \\
\hline 2 & $1.80-2.59$ & Disagree & & & & & & & \\
\hline 1 & 1:00-1.79 & Strongly Disagree & & & & & & & \\
\hline
\end{tabular}

The International Atomic Energy Agency documented that one of the challenges for nuclear medicine is the radiopharmacist shortfall, there is an acute scarcity or even absence of pharmacists with radiopharmacy training. ${ }^{10}$ The Philippine Nuclear Research Institute as mandated by Republic Act 5207 or the Atomic Energy Regulatory and Liability Act, only approves atomic energy facilities only approves an application for a license to manufacture and dispense radiopharmaceuticals if the company designates an authorized nuclear pharmacist or radio pharmacist, hence, the need to train additional pharmacists. ${ }^{11}$

In the current research, healthcare professionals strongly agreed that radiopharmacists are needed in a multidisciplinary nuclear pharmacy practice team. This means that pharmacists' role is necessary and must be recognized as primary part in managing and handling radiopharmaceuticals since the activities in radiopharmacy such as ordering, procurement, dispensing and monitoring are parallel to the scope of work of traditional hospital pharmacy. Similarly, in a study conducted by Riyasha et al,..$^{4}$ that all the respondents showed willingness towards the concept of a radiopharmacist in Sri Lanka.

It can be noted that radiopharmacy is not recognized in most Asian countries. ${ }^{12}$ This is seemingly true in the Philippines. This can be attributed to lack of education or training background of pharmacists. There is an insufficiently applied concept of radio and nuclear pharmacy in an undergraduate curriculum. Moreover, a course on nuclear pharmacy is offered to a few masters and Ph.D. in Pharmacy programs and those who intend to practice nuclear pharmacy practice must undergo special training at the PNRI with a fee. This could probably be due to lack of specific legislation or regulation which may limit the implementation and developments in radiopharmacy in the country.

Thus, many potential pharmacists inadequately know about applied aspects of radio and nuclear pharmacy, its application, clinical and therapeutic application, quality assurance, employment and remuneration, prospect, contribution and work-role of radiopharmacist in the management of patients and real health care setting. Therefore, applied concepts of radiopharmacy and related aspects must be included in the undergraduate curriculum and appropriate legislation must be established in the country.

\section{CONCLUSION}

Based on the respondents' knowledge and perception, the services of radiopharmacists in hospitals in the Philippines are needed to ensure proper handling and management of radiopharmaceuticals for better health outcomes and patient safety. Pharmacist primarily contributed this propensity since it is the profession that radiopharmacist should emerge.

\section{Recommendations}

Future researchers may venture to the national level since this study is limited only to the countryside perspective. Patients' and students' perspectives can also be done to precisely assess the need for radiopharmacist in the country. 


\section{ACKNOWLEDGEMENT}

We acknowledge the management of the hospitals where the study was conducted.

\section{CONFLICT OF INTEREST}

The authors declare no conflict of interest.

\section{ABBREVIATIONS}

SPSS: Statistical Package for the Health Sciences; MD: Medical Doctor or Doctor of Medicine; RN: Registered Nurse; RPh: Registered Pharmacist; RMT: Registered Medical Technologist; RRT: Registered Respiratory Therapist.

\section{SUMMARY}

Radiopharmacists are deemed necessary in the country in order to optimize the proper use of radiopharmaceuticals to ensure quality patient health outcomes and safety.

\section{REFERENCES}

1. Brasil MP, De Barros MP, Antunes LJ, Santos-Oliveira R. Hospital nuclear pharmacy survey: preliminary aspects in Brazil. J Young Pharm. 2012;4(4):279-81. doi: 10.4103/0975-1483.104373, PMID 23493051.
2. Patel $\mathrm{J}$, Bhatt $\mathrm{S}$. Clinical pharmacist in nuclear medicine: $\mathrm{A}$ new role in ascendancy. Indian J Pharm Pract. 2014;7(3):14-8. doi: 10.5530/ijopp.7.3.4.

3. Patidar AK, Patidar P, Tandel TS, Mobiya AK, Selvam G, Jeyakandan M. Current trends in nuclear pharmacy practice. Int $\mathrm{J}$ Pharm Sci Rev Res. 2010;5(2):145-51.

4. Jamshed S, Riyasha F, Hameem S. The need of radiopharmacist in Sri Lanka. Arch Pharma Pract. 2013;4(4):190-1. doi: 10.4103/2045-080X.123232.

5. Parasuraman S, Mueen Ahmed KK, Bin Hashim TS, Muralidharan S, Kumar KJ, Ping WY, Syamittra B, Dhanaraj SA. Knowledge about the availability of the pharmacist in the Nuclear Medicine Department: A questionnaire-based study among health-care professionals. J Basic Clin Pharm. 2014;6(1):19-23. doi: 10.4103/0976-0105.145773. PMID 25538467.

6. Bautista PA, Luis TOL. Nuclear medicine in the Philippines: A glance at the past, a gaze at the present, and a glimpse of the future. Asia Ocean J Nucl Med Biol. 2016;4(2):113-8. doi: 10.7508/aojnmb.2016.02.009, PMID 27408901.

7. Beach TA, Griffith K, Dam HQ, Manzone TA. Ensuring safe and quality medication use in nuclear medicine: A collaborative team achieves compliance with medication management standards. J Nucl Med Technol. 2012;40(1):1-10. doi: 10.2967/jnmt.111.094268, PMID 22279239.

8. Riyasha F, Hameem S, Jamshed SQ. An exploratory study to ascertain the need of radiopharmacist in Sri Lanka. Int J Pharm Pharm Sci. 2015;7(2):548-53.

9. Philippine Nuclear Research Institute. CPR Part 20. Licenses to manufacture and dispense radiopharmaceuticals. Off Gaz. 2002;98(26).

10. Competency Based Hospital. Radiopharmacy training. Austria: International Atomic Energy Agency; 2010.

11. The LawPhil project. Republic act. Vol. 5207 [internet]. Available from: https:// www.lawphil.net/statutes/repacts/ra1968 [cited 22/10/2021].

12. Lutz R. Nuclear pharmacists' role not recognized by healthcare professionals. Pharmacy Times. Available from: http://www.pharmacytimes.com/news/ nuclear-pharmacists-role-not-recognized-by-health-care-professionals; 2015. 